\title{
Exogenous dietary xylanase ameliorates viscosity-induced anti-nutritional effects in wheat-based diets for White Pekin ducks (Anas platyrinchos domesticus)†
}

\author{
Olayiwola Adeola ${ }^{1}$ and Michael R. Bedford ${ }^{2}$ \\ ${ }^{1}$ Department of Animal Sciences, Purdue University, West Lafayette, IN 47907, USA \\ ${ }^{2}$ Finnfeeds International Ltd, Marlborough, Wilts., UK
}

(Received 5 November 2003 - Revised 15 March 2004 - Accepted 29 March 2004)

\begin{abstract}
Nutrient utilisation and growth performance responses of White Pekin ducks (Anas platyrinchos domesticus) offered diets containing lowor high-viscosity wheat supplemented with xylanase were investigated in two studies. In Expt 1, six diets consisting of low-viscosity wheat or high-viscosity wheat supplemented with $0.0,1.5$ or $3.0 \mathrm{~g}$ xylanase $(2590$ units $/ \mathrm{g}) / \mathrm{kg}$ diet were used in a true metabolisable energy (TME) bioassay with eight 8-week-old ducks per diet group. In Expt 2, eight pens of ten 3-d-old ducks per pen for each of six wheatbased diets arranged in a $2 \times 3$ factorial of low-viscosity or high-viscosity wheat and $0.0,1.5$ or $3.0 \mathrm{~g}$ xylanase $/ \mathrm{kg}$ were used in a $42 \mathrm{~d}$ growth study. High-viscosity wheat depressed $(P<0.001)$ TME and xylanase supplementation improved $(P<0.001)$ TME, more so for high-viscosity than low-viscosity wheat. Xylanase supplementation of the high-viscosity wheat-based diet improved $(P<0 \cdot 05)$ weight gain and gain:feed ratio by 13 and $12 \%$ respectively. There was no weight gain or gain:feed ratio response to xylanase supplementation of the low-viscosity wheat-based diet. Xylanase supplementation reduced $(P<0.001)$ the viscosity of duodenal and ileal digesta for highviscosity but not low-viscosity wheat-based diets. Ileal digestibilities of nutrients and energy were higher $(P<0 \cdot 001)$ for low-viscosity than high-viscosity wheat-based diets; xylanase supplementation improved $(P<0.05)$ energy, fat, $\mathrm{N}$ and starch digestibilities. Given that xylanase supplementation of high-viscosity wheat assuaged its anti-nutritional effect, it is surmised that digesta viscosity plays a role in antinutritional effects in wheat-based diets for ducks.
\end{abstract}

White Pekin ducks: Wheat: Xylanase: Viscosity: Nutrient digestibility

The preponderance of literature indicates that NSP at high levels in grains reduces nutrient utilisation and growth performance in broiler chicks (Bedford \& Classen, 1992; Choct et al. 1996; Carre et al. 2002). Addition of enzymes to diets based on these grains has been shown to reduce the anti-nutritional effects when these diets are fed to broiler chicks (Annison, 1992; Bedford \& Classen, 1992). The major pentosan in the endosperm cell wall of wheat is arabinoxylan, and consists of a (1-4)- $\beta$-xylan chain with $\alpha$-arabinose units substituted at the 2 and 3 positions of the xylose, and exhibits a considerable variation in molecular mass and in xylose:arabinose ratio (Fincher \& Stone, 1986). It is well documented in broiler chickens that water-soluble pentosans native to grains such as rye and wheat, or their addition to maize-based diets not only increase viscosity, but also reduce growth performance (Bedford \& Classen, 1992) and digestion of energy, starch and fat (Langhout et al. 2000). Furthermore, studies by Friesen et al. (1992) established that the performance of broiler chickens fed wheat-based diets was linearly related to the logarithm of intestinal viscosity. A fundamental question of nutritional importance is whether the viscosity of wheat in diets offered to ducks affects growth performance and whether xylanase supplementation of such diets for ducks improves growth performance via a reduction in intestinal digesta viscosity and improvement in nutrient utilisation. Supplementation of rye-based (Bedford \& Classen, 1992) or wheat-based (Brenes et al. 1993) diets with xylanase improved growth performance by a reduction in ileal digesta viscosity and through a reduction in gastrointestinal tract weight of broiler chickens respectively. Some differences exist between chickens and ducks with respect to digestive physiology. Unlike chickens, ducks have a spindle-shaped widening of the oesophagus and fusiform proventriculus, which may promote a quicker transit rate of ingesta. The enlarged diverticulum of the oesophagus in the duck lacks definite musculature for the control of feed passage (entry into and exit from); thus, there is no true crop in the duck. The pseudo-crop in the duck serves as a temporary storage organ for lubrication

\footnotetext{
Abbreviations: TME, true metabolisable energy; TMEn, true metabolisable energy corrected for nitrogen.

* Corresponding author: Professor Olayiwola Adeola, fax + 765464 9346, email ladeola@purdue.edu

$\dagger$ Journal paper no. 17248 of the Purdue University Agricultural Research Program.
} 
and softening of feed. The water:food intake ratios are 4.2:1.0 and 2.3:1.0 for ducks and chickens respectively (Scott \& Dean, 1991). Greater water intake would result in greater digesta water content and this could translate into reduced digesta viscosity. Therefore, the negative impact of high-viscosity feed ingredients on growth performance may not be as severe in ducks as in chickens.

To date there have not been any studies addressing whether any growth performance improvement from exogenous xylanase supplementation of wheat-based diets for ducks derives from intestinal digesta viscosity-related changes in nutrient utilisation. The present study investigated the intestinal digesta viscosity, nutrient utilisation and growth performance of White Pekin ducks (Anas platyrinchos domesticus) offered diets containing wheat of low or high viscosity supplemented with xylanase at 0.0 , 1.5 or $3.0 \mathrm{~g} / \mathrm{kg}$. Thus, we tested the hypotheses that: (1) increases in the viscosity of wheat in diets offered to ducks depress growth performance; (2) xylanase supplementation of such diets for ducks reduces intestinal digesta viscosity and improves nutrient utilisation and growth performance.

\section{Materials and methods}

\section{Xylanase and animals}

The xylanase preparation was derived from Trichoderma longibrachiatum; the preparation contained 2590 units/g (1 unit is eqivalent to $1 \mu \mathrm{mol}$ reducing sugar released/ min per g enzyme preparation at $40^{\circ} \mathrm{C}, \mathrm{pH} 4.8$ ) and had $\beta$-glucanase activity, albeit very low. This preparation is one of the enzymes in Avizyme ${ }^{\circledR} 1500$ series and was obtained from Finnfeeds International Ltd (Marlborough, Wilts., UK). The animals used in the present study were White Pekin ducks. The viscosities of low- and high-viscosity wheat (Triticum aestivum var. genesis, grown in Saskatoon, Sask., Canada, and shipped to Purdue University) were measured as 5.86 and $45.68 \mathrm{mPa} \cdot \mathrm{s}$. Details of wheat analysis and screening that lead to the selection of these low-viscosity and high-viscosity wheat types have been described by Scott et al. (1998). The chemical analyses of wheat and soyabean meal used in the studies are presented in Table 1.

\section{True metabolisable energy bioassay}

Fifty-six 8-week-old White Pekin male ducks with average body weight $3.8 \mathrm{~kg}$ were sorted according to initial weight and assigned to six dietary treatment groups and one feeddeprived group such that average weights across the seven groups were similar (eight ducks per group). The ducks were randomly assigned to individual cages $(0.66 \times 0.66 \mathrm{~m})$ and housed in an environmentally controlled room, where a temperature of $25^{\circ} \mathrm{C}$ was maintained. Fluorescent bulbs provided continuous $(24 \mathrm{~h})$ lighting. The eight ducks assigned to the feed-deprived group were fed dextrose for the estimation of endogenous losses of energy and N (Sibbald, 1979; McNab \& Blair, 1988). The six experimental diets consisted of low-viscosity
Table 1. The chemical analysis of wheat and soyabean meal $(\mathrm{g} / \mathrm{kg})$

\begin{tabular}{|c|c|c|c|}
\hline & $\begin{array}{c}\text { Low-viscosity } \\
\text { wheat }\end{array}$ & $\begin{array}{l}\text { High-viscosity } \\
\text { wheat }\end{array}$ & $\begin{array}{c}\text { Soyabean } \\
\text { meal }\end{array}$ \\
\hline DM & 904 & 905 & 913 \\
\hline $\begin{array}{l}\text { Crude protein } \\
(\mathrm{N} \times 6.25)\end{array}$ & 166 & 130 & 489 \\
\hline Diethyl ether extract & $16 \cdot 5$ & $11 \cdot 8$ & $11 \cdot 2$ \\
\hline Ash & 17.5 & $18 \cdot 2$ & $57 \cdot 7$ \\
\hline Crude fibre & $20 \cdot 2$ & 30.4 & 30 \\
\hline $\mathrm{NSP}^{*}$ & 94 & 153 & 290 \\
\hline Energy $(\mathrm{kJ} / \mathrm{g})$ & $16 \cdot 82$ & $16 \cdot 28$ & 17.59 \\
\hline Viscosity (mPa.s) & $5 \cdot 86$ & $45 \cdot 68$ & - \\
\hline \multicolumn{4}{|l|}{ Essential amino acids } \\
\hline Arg & $7 \cdot 1$ & $6 \cdot 8$ & 34.9 \\
\hline His & 3.6 & 2.9 & $12 \cdot 7$ \\
\hline Ile & $5 \cdot 2$ & 3.7 & $21 \cdot 2$ \\
\hline Leu & 10.4 & 8.2 & 37.2 \\
\hline Lys & 4.0 & $3 \cdot 3$ & 29.9 \\
\hline Met & 2.4 & $2 \cdot 0$ & 6.9 \\
\hline Phe & $7 \cdot 2$ & $5 \cdot 1$ & $24 \cdot 1$ \\
\hline Thr & 4.3 & $3 \cdot 1$ & $19 \cdot 0$ \\
\hline Trp & $2 \cdot 0$ & 1.6 & $6 \cdot 8$ \\
\hline Val & $6 \cdot 4$ & 4.9 & $22 \cdot 3$ \\
\hline \multicolumn{4}{|c|}{ Non-essential amino acids } \\
\hline Ala & $5 \cdot 3$ & $4 \cdot 1$ & $20 \cdot 8$ \\
\hline Asp & 7.4 & $7 \cdot 6$ & 53.8 \\
\hline Cys & 3.6 & $3 \cdot 2$ & 7.3 \\
\hline Glu & 43.5 & $36 \cdot 7$ & 84.0 \\
\hline Gly & $6 \cdot 3$ & $5 \cdot 3$ & 20.2 \\
\hline Pro & 14.9 & $10 \cdot 6$ & 24.0 \\
\hline Ser & 6.4 & 4.3 & $22 \cdot 2$ \\
\hline Tyr & $4 \cdot 1$ & 3.6 & $17 \cdot 1$ \\
\hline
\end{tabular}

* Calculated as the difference between analysed DM and the sum of analysed crude protein $(\mathrm{N} \times 6 \cdot 25)$, crude fat, starch, sugar and ash.

or high-viscosity wheat supplemented with $0.0,1.5$ or $3.0 \mathrm{~g} / \mathrm{kg}$ diet in a $2 \times 3$ factorial arrangement.

Approximately $3 \mathrm{~d}$ before the start of the experiment, each duck was surgically fitted with modified plastic retainer lids from a Playtex ${ }^{\mathrm{TM}}$ nurser bottle set (Playtex Products, Dover, DE, USA) as described by Adeola et al. (1997). Briefly, the ducks were restrained in a Plexiglass box and feathers around the vent were removed. Lidocaine hydrochloride $(20 \mathrm{ml} / \mathrm{l} ; 4 \mathrm{ml})$ was injected around the vent to desensitise the area $(1 \mathrm{ml}$ in each of four regions). A continuous suture was applied to secure the retainer ring to the skin. The plastic bottle of the nurser set was measured and cut to a length of $30 \mathrm{~mm}$ below the threads on the bottle and Whirl-Pak bags (Nasco, Fort Atkinson, WI, USA) inserted into the bore of the bottle, so that the edges of the bags hung over the threads of the bottle. During excreta collection, the bottle and Whirl-Pak bag were then screwed onto the modified retainer ring attached to the duck. The feeding method and assay to determine true metabolisable energy corrected for N (TMEn) used in the present experiment followed standard techniques devised by Sibbald (1976) and the modifications suggested by McNab \& Blair (1988). Protocols for feeding and excreta collection were published in Table 1 of King et al. (2000). All procedures were approved by the Purdue University Animal Care and Use Committee.

\section{Growth performance}

Male White Pekin ducks ( $n$ 480, 1-d-old) were wingbanded and housed in pens $(1.05 \times 3.66 \mathrm{~m})$ containing ten 
ducks per pen with a daily lighting regimen of $23 \mathrm{~h}$ light and $1 \mathrm{~h}$ dark. Ducks were fed on a pelleted commercial diet $(230 \mathrm{~g}$ crude protein $(\mathrm{N} \times 6 \cdot 25) / \mathrm{kg})$ for the first $2 \mathrm{~d}$. Room temperature was maintained at $35^{\circ} \mathrm{C}$ in the first week and was reduced by $2^{\circ} \mathrm{C}$ every week until the temperature reached $25^{\circ} \mathrm{C}$ at the end of the experiment. Ducks had unrestricted access to experimental diets and nipple drinkers throughout the experiment.

All the wing-banded ducks ( $n$ 480) were weighed individually on day 3 and assigned to six groups so that the average initial weights of ducks were similar across dietary treatments with ten ducks per pen and eight pens per diet. The ducks were fed starter diets $(220 \mathrm{~g}$ crude protein $(\mathrm{N} \times 6.25) / \mathrm{kg})$ for 2 weeks. The ingredient composition of the basal diets is presented in Table 2. The six diets were arranged in a $2 \times 3$ factorial of low-viscosity or high-viscosity wheat and $0.0,1.5$, or $3.0 \mathrm{~g}$ xylanase $/ \mathrm{kg}$. All diets were fed in mash form throughout the experiment. At the end of 2 weeks, ducks were switched to and maintained on grower diets $(160 \mathrm{~g}$ crude protein $(\mathrm{N} \times 6 \cdot 25) / \mathrm{kg})$ for 4 weeks, and remained on xylanase treatments $(0.0,1.5$ or $3.0 \mathrm{~g} / \mathrm{kg}$ ) for the $42 \mathrm{~d}$ study. Body weight and feed intake were monitored weekly with pen as the experimental unit.

\section{Digesta viscosity and nutrient utilisation}

At the end of the $42 \mathrm{~d}$ growth performance study, ducks were maintained on their respective diets, which were mixed with $3 \mathrm{~g} \mathrm{Cr}_{2} \mathrm{O}_{3} / \mathrm{kg}$. After $5 \mathrm{~d}$, the ducks were killed with $\mathrm{CO}_{2}$. The total intestinal contents were collected from the duodenum and ileum (from the Meckel's diverticulum to the ileo-caecal junction). Samples from six ducks within a pen were pooled for the analysis of $\mathrm{Cr}$, N, starch, fat and energy. Samples were analysed for viscosity immediately following collection (Bedford \& Classen, 1992). All the remaining digesta were frozen immediately after collection.

\section{Chemical analysis}

The pooled and homogenised samples for viscosity measurement were centrifuged at $15000 \mathrm{~g}$ for $15 \mathrm{~min}$ at $20^{\circ} \mathrm{C}$. Viscosity was determined on a $0.5 \mathrm{ml}$ supernatant fraction using a Brookfield viscometer (model LVTDVCP-II; Brookfield Engineering Laboratories, Stoughton, MA, USA) maintained at $25^{\circ} \mathrm{C}$ and a shear rate of $5 \cdot 0-22 \cdot 5 \mathrm{~s}^{-1}$. The measurement of $\mathrm{pH}$ value was carried out using a one-pin electrode. All the measurements were made within $12 \mathrm{~min}$ of death. The frozen excreta and ileal digesta samples were thawed, transferred to $\mathrm{Al}$ pans and placed in a $50^{\circ} \mathrm{C}$ oven for $120 \mathrm{~h}$. After drying, all samples were ground through a $0.5 \mathrm{~mm}$ screen to facilitate analysis. DM contents of the diets, excreta and ileum samples were determined by oven-drying at $105^{\circ} \mathrm{C}$ for $24 \mathrm{~h}$. Cr was analysed as described by Czarnocki et al. (1961). N content of samples was determined by the combustion method, using an LECO Model FP 2000 combustion analyser (LECO Corp., St Joseph, MI, USA). Energy content of the samples was determined by bomb calorimetry using Parr 1261 adiabatic calorimeter (Parr Instrument Co., Moline, IL, USA). Starch and fat were determined by the University of Missouri Chemistry Laboratory (Association of Official Analytical Chemists, 1995).

Table 2. Ingredient $(\mathrm{g} / \mathrm{kg})$ and nutrient $(\mathrm{g} / \mathrm{kg})$ composition of the basal diets

\begin{tabular}{|c|c|c|c|c|}
\hline \multirow[b]{2}{*}{ Wheat type... } & \multicolumn{2}{|c|}{ Starter diet (days $0-14$ ) } & \multicolumn{2}{|c|}{ Grower diet (days 14-42) } \\
\hline & Low-viscosity & High-viscosity & Low-viscosity & High-viscosity \\
\hline \multicolumn{5}{|l|}{ Ingredient } \\
\hline Wheat & 695 & 618 & 780 & 721 \\
\hline Soyabean meal & 237 & 315 & 89 & 150 \\
\hline Fat blend & 30 & 30 & 25 & 25 \\
\hline Dicalcium phosphate & 18 & 18 & 15 & 15 \\
\hline Limestone & 10 & 10 & 10 & 10 \\
\hline Salt & 4 & 4 & 4 & 4 \\
\hline Vitamins and minerals* & 3 & 3 & 3 & 3 \\
\hline Lysine, hydrochloride & 1 & 1 & 2 & 2 \\
\hline DL-Methionine & 2 & 2 & 2 & 2 \\
\hline Wheat middlings & - & - & 70 & 70 \\
\hline Enzyme† & - & - & - & - \\
\hline Total & 1000 & 1000 & 1000 & 1000 \\
\hline \multicolumn{5}{|c|}{ Analysed nutrient composition (DM basis) } \\
\hline Energy $(\mathrm{kJ} / \mathrm{g})$ & $18 \cdot 88$ & $18 \cdot 36$ & $17 \cdot 61$ & $16 \cdot 85$ \\
\hline Crude protein $(\mathrm{N} \times 6.25)$ & 230 & 234 & 172 & 177 \\
\hline Lysine & $10 \cdot 7$ & 11 & $7 \cdot 1$ & 7.5 \\
\hline S-amino acids & $8 \cdot 6$ & $9 \cdot 1$ & $6 \cdot 9$ & $7 \cdot 2$ \\
\hline $\mathrm{Ca}$ & 8.4 & $8 \cdot 6$ & $7 \cdot 4$ & $7 \cdot 6$ \\
\hline Non-phytate $\mathrm{P}$ & 5.9 & $5 \cdot 8$ & $5 \cdot 3$ & $5 \cdot 3$ \\
\hline
\end{tabular}

* Provided the following (per $\mathrm{kg}$ diet): retinol $1.65 \mathrm{mg}$, cholecalciferol $66 \mu \mathrm{g}$, DL- $\alpha$ tocopherol $10 \mathrm{mg}$, menadione sodium bisulfite $438 \mathrm{mg}$, riboflavin $5.49 \mathrm{mg}$, D-pantothenic acid $11 \mathrm{mg}$, niacin $44.1 \mathrm{mg}$, choline chloride $771 \mathrm{mg}$, cyanocobalamin, $13.2 \mathrm{mg}$, biotin $55.2 \mu \mathrm{g}$, thiamine monocitrate $2.2 \mathrm{mg}$, folic acid $990 \mu \mathrm{g}$, pyridoxine hydrochloride $3.3 \mathrm{mg}, \mathrm{I} 1.11 \mathrm{mg}$, Mn $66 \mathrm{mg}$, Cu $4.44 \mathrm{mg}$, Fe $44.1 \mathrm{mg}$, Zn $44.1 \mathrm{mg}$, Se $300 \mu \mathrm{g}$.

†Xylanase replaced wheat at $0.0,1.5$ or $3.0 \mathrm{~g} / \mathrm{kg}$ diet. 


\section{Calculations and statistical analyses}

The following equations were used for calculation of nutrient and energy digestibilities and retentions:

$$
\begin{aligned}
& \text { digestibility }(\%)=100 \\
&-\left(100 \times\left(\operatorname{diet} \mathrm{Cr}_{2} \mathrm{O}_{3} / \text { ileal digesta } \mathrm{Cr}_{2} \mathrm{O}_{3}\right)\right. \\
& \times(\text { ileal digesta nutrient or energy } \\
&/ \text { diet nutrient or energy })), \\
& \mathrm{TME}=(\mathrm{EI}-\mathrm{EO}) / \mathrm{FI}+(\mathrm{FEL} / \mathrm{FI}), \\
& \mathrm{TMEn}=\mathrm{TME}-(34.39 \times \mathrm{ANR} / \mathrm{FI})-(34.39 \times \mathrm{FNL} / \mathrm{FI})
\end{aligned}
$$

and

$$
\operatorname{ANR}(\%)=100 \times(\mathrm{NI}-\mathrm{NO}) / \mathrm{NI},
$$

where TME is true metabolisable energy $(\mathrm{kJ})$, EI is gross energy intake $(\mathrm{kJ}), \mathrm{EO}$ is the gross energy output $(\mathrm{kJ})$, FI is feed intake $(\mathrm{g})$, ANR is apparent $\mathrm{N}$ retention $(\mathrm{N}$ intake - $\mathrm{N}$ output) ( $\mathrm{g}$ ), FEL is fasting energy loss from the group of feed-deprived ducks that received dextrose and FNL is fasting $\mathrm{N}$ loss $(\mathrm{g}), 34.39 \mathrm{~kJ}$ is the energy equivalent per $\mathrm{g}$ uric acid $\mathrm{N}, \mathrm{NI}$ is $\mathrm{N}$ intake $(\mathrm{g})$ and $\mathrm{NO}$ is $\mathrm{N}$ output in the excreta $(\mathrm{g})$. All experimental data were analysed as a two-factor factorial arrangement of treatments in a randomised complete block design with initial weight as blocking factor, and performed using the GLM procedure of SAS release $8 \cdot 2$ (Statistical Analysis Systems, Cary, NC, USA). Means within the two wheat types were separated using linear and quadratic contrasts.

\section{Results}

The results of $\mathrm{N}$ and energy utilisation for ducks in the TMEn study are presented in Table 3. The effects of wheat type and xylanase supplementation were both significant $(P<0.001)$ for the apparent DM retention of ducks. Xylanase effects on DM retention were more pronounced with high-viscosity than low-viscosity wheat as seen in the interaction $(P<0 \cdot 001)$ between xylanase and wheat type. Xylanase supplementation of the high-viscosity wheat-based diet resulted in a linear improvement $(P<0.05)$ in apparent $\mathrm{N}$ retention; however, no detectable effects on apparent $\mathrm{N}$ retention were observed when xylanase was added to low-viscosity wheat-based diet. The TMEn values of six diets were less than corresponding TME values, because the ducks used in the present study were in positive $\mathrm{N}$ balance. High-viscosity wheat depressed $(P<0.001)$ both TME and TMEn (Table 3). Xylanase supplementation improved $(P<0.001)$ both TME and TMEn, more so for high-viscosity wheat as indicated by a significant interaction $(P<0 \cdot 001)$.

During the starter phase of the experiment (days 0-14), weight gain and gain:feed ratio of ducks offered low-viscosity wheat were greater $(P<0.001)$ than those offered high-viscosity wheat-based diets; xylanase supplementation had no effects on weight gain and gain:feed ratio (Table 4). During the grower phase (days 14-42), xylanase supplementation of diets linearly improved $(P<0 \cdot 001)$ weight gains and feed efficiencies for ducks offered diets containing high-viscosity wheat, but this was not the case for low-viscosity wheat-based diets. For the 6-week study, the high-viscosity wheat-induced depression in weight gain and gain:feed ratio were attenuated $(P<0.001)$ by xylanase supplementation (Table 4$)$.

The viscosity of duodenal and ileal digesta in ducks that received the high-viscosity wheat-based diet was greater $(P<0.01)$ than those that received low-viscosity wheatbased diet (Table 5). Xylanase supplementation decreased $(P<0.001)$ the viscosity of duodenal and ileal digesta in ducks that received the high-viscosity wheat-based diet, but not in ducks that received the low-viscosity wheat-

\begin{tabular}{|c|c|c|c|c|c|c|c|c|c|c|}
\hline \multirow{2}{*}{$\begin{array}{l}\text { Wheat type... } \\
\text { Xylanase }(\mathrm{g} / \mathrm{kg}) \ldots \ddagger\end{array}$} & \multicolumn{3}{|c|}{ Low-viscosity } & \multicolumn{3}{|c|}{ High-viscosity } & \multirow[b]{2}{*}{ SD } & \multicolumn{3}{|c|}{$\begin{array}{l}\text { Statistical signifi- } \\
\text { cance of effect }\end{array}$} \\
\hline & $0 \cdot 0$ & 1.5 & $3 \cdot 0$ & 0.0 & 1.5 & $3 \cdot 0$ & & W & $X$ & $\mathrm{~W} \times \mathrm{X}$ \\
\hline$n \S$ & 8 & 8 & 8 & 8 & 8 & 8 & - & & & \\
\hline Apparent DM retention (\%)\|ף & $80 \cdot 80$ & $80 \cdot 29$ & $81 \cdot 85$ & $80 \cdot 08$ & 84.01 & 84.47 & $1 \cdot 273$ & *** & $\star \star \star *$ & *** \\
\hline Apparent $\mathrm{N}$ retention $(\%) \dagger \dagger$ & 58.93 & $50 \cdot 64$ & $48 \cdot 81$ & $50 \cdot 47$ & $64 \cdot 26$ & $65 \cdot 11$ & $13 \cdot 620$ & NS & NS & * \\
\hline True metabolisable energy $(\mathrm{kJ} / \mathrm{g})\|\S \S\| \|$ & 14.95 & $14 \cdot 97$ & $15 \cdot 15$ & $14 \cdot 23$ & $14 \cdot 84$ & $14 \cdot 75$ & $0 \cdot 155$ & 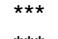 & 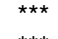 & 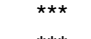 \\
\hline
\end{tabular}
based diet. Neither wheat type nor xylanase supplementation had an effect $(P>0.05)$ on the $\mathrm{pH}$ of duodenal digesta; however, ileal digesta $\mathrm{pH}$ was reduced $(P<0 \cdot 01)$ for the high-viscosity compared with low-viscosity

Table 3. Nitrogen and energy utilisation for White Pekin ducks (Anas platyrinchos domesticus) fed on wheat-based diets (Mean values)

W, wheat type; $X$, xylanase $(0.0,1.5$ or $3.0 \mathrm{~g} / \mathrm{kg}$ diet $)$

${ }^{\star} P<0.05,{ }^{* \star \star} P<0.001$.

†For details of diets and procedures, see Tables 1 and 2 and pp. 88-89.

$\ddagger$ Xylanase preparation was derived from Trichoderma longibrachiatum and determined to contain 2590 units $/ \mathrm{g}(1 \mathrm{unit}=1 \mu \mathrm{mol} \mathrm{reducing}$ sugar released/min per $\mathrm{g}$ enzyme preparation at $40^{\circ} \mathrm{C}, \mathrm{pH} 4.8$ ).

$\S$ Number of ducks for each dietary treatment.

\| Linear response to enzyme supplementation for high-viscosity wheat at $P<0.001$.

- Quadratic response to enzyme supplementation for high-viscosity wheat at $P<0.01$.

†† Linear response to enzyme supplementation for high-viscosity wheat at $P<0.05$.

$\S \S$ Linear response to enzyme supplementation for low-viscosity wheat at $P<0.05$.

\|II Quadratic response to enzyme supplementation for high-viscosity wheat at $P<0.001$.

9 ๆ Linear response to enzyme supplementation for low-viscosity wheat at $P<0.001$. 
Table 4. Body weight and growth performance for White Pekin ducks (Anas platyrinchos domesticus) fed on wheat-based diets $\dagger$ (Mean values)

\begin{tabular}{|c|c|c|c|c|c|c|c|c|c|c|}
\hline \multirow{2}{*}{$\begin{array}{l}\text { Wheat type... } \\
\text { Xylanase }(\mathrm{g} / \mathrm{kg}) \ldots \neq\end{array}$} & \multicolumn{3}{|c|}{ Low-viscosity } & \multicolumn{3}{|c|}{ High-viscosity } & \multirow[b]{2}{*}{ SD } & \multicolumn{3}{|c|}{$\begin{array}{c}\text { Statistical significance of } \\
\text { effect }\end{array}$} \\
\hline & 0.0 & 1.5 & $3 \cdot 0$ & 0.0 & 1.5 & $3 \cdot 0$ & & W & $\mathrm{X}$ & $W \times X$ \\
\hline$n \S$ & 8 & 8 & 8 & 8 & 8 & 8 & - & & & \\
\hline \multicolumn{11}{|c|}{ Body weight (kg per bird) } \\
\hline Initial & 0.047 & 0.047 & 0.047 & 0.047 & 0.047 & 0.047 & & & & \\
\hline Day 14 & 0.587 & 0.594 & 0.600 & 0.546 & 0.562 & 0.561 & 0.023 & $\star \star \star \star ~$ & NS & NS \\
\hline Day 42\|ף & $2 \cdot 952$ & $2 \cdot 917$ & $2 \cdot 970$ & 2.527 & 2.858 & $2 \cdot 813$ & 0.123 & 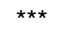 & $\star \star *$ & $\star * \star *$ \\
\hline \multicolumn{11}{|c|}{ Weight gain (kg per bird) } \\
\hline Day $0-14$ & 0.540 & 0.547 & 0.553 & 0.500 & 0.515 & 0.515 & 0.023 & $\star \star \star \star ~$ & NS & NS \\
\hline Day $14-42 \| \rrbracket$ & 2.364 & $2 \cdot 322$ & 2.369 & 1.980 & $2 \cdot 297$ & $2 \cdot 252$ & 0.113 & $\star \star \star \star ~$ & $\star \star \star$ & 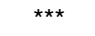 \\
\hline Day 0-42\|ף & $2 \cdot 906$ & $2 \cdot 870$ & 2.923 & $2 \cdot 481$ & $2 \cdot 812$ & $2 \cdot 767$ & 0.123 & 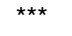 & *** & 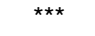 \\
\hline \multicolumn{11}{|c|}{ Feed intake (kg per bird) } \\
\hline Day 0-14 & 0.809 & 0.845 & 0.833 & $0 \cdot 876$ & 0.888 & 0.886 & 0.048 & $\star \star \star \star ~$ & NS & NS \\
\hline Day $14-42$ & $5 \cdot 299$ & $5 \cdot 317$ & $5 \cdot 254$ & $5 \cdot 183$ & $5 \cdot 413$ & $5 \cdot 270$ & 0.240 & NS & NS & NS \\
\hline Day 0-42 & $6 \cdot 109$ & $6 \cdot 163$ & 6.088 & $6 \cdot 060$ & $6 \cdot 302$ & $6 \cdot 155$ & 0.258 & NS & NS & NS \\
\hline \multicolumn{11}{|c|}{ Gain : feed ratio ( $\mathrm{kg}$ gain $/ \mathrm{kg}$ feed) } \\
\hline Day 0-14 & 0.668 & 0.650 & 0.666 & 0.571 & 0.581 & 0.581 & 0.025 & 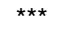 & NS & NS \\
\hline Day $14-42 \| \dagger \dagger$ & 0.446 & 0.437 & 0.451 & 0.382 & 0.426 & 0.428 & 0.022 & *** & ** & $\star \star \star$ \\
\hline Day 0-42\|†† & 0.476 & 0.466 & 0.480 & 0.409 & 0.447 & 0.450 & 0.019 & $* * *$ & ** & ** \\
\hline \multicolumn{11}{|c|}{ 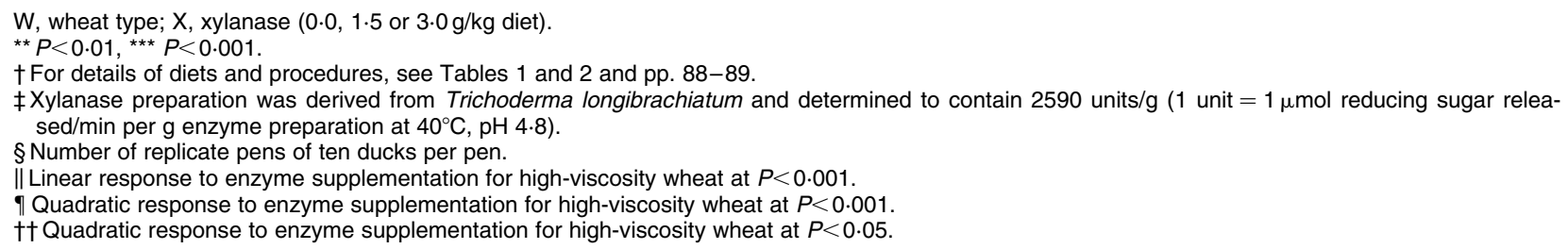 } \\
\hline
\end{tabular}

wheat-based diet. Supplementation of the high-viscosity wheat-based diet with xylanase increased $(P<0 \cdot 01)$ ileal digesta $\mathrm{pH}$, but this effect was not seen with low-viscosity wheat-based diet. Xylanase supplementation was observed to improve $(P<0.05)$ starch, fat and energy digestibility regardless of wheat type (Table 6). Ileal digestibilities of nutrients and energy were greater $(P<0.001)$ for ducks offered diets containing low-viscosity than high-viscosity wheat-based diets. The wheat $\times$ xylanase interaction was significant only for starch digestibility $(P<0.01)$ and the effect of xylanase was more pronounced for ducks offered the high-viscosity wheat-based diet.

\section{Discussion}

One of the main questions addressed in the present study was whether a high-viscosity wheat-based diet affects growth performance of ducks. Indeed, the present results suggest that feeding the high-viscosity wheat-based diets depressed 6-week weight gain and gain:feed ratio by 15 and $14 \%$ respectively. To identify the underlying factors that govern this observation, we measured the viscosities and $\mathrm{pH}$ of duodenal and ileal digesta collected from these ducks, and determined digestibilities of energy and nutrients. Feeding the high-viscosity wheat-based diet

Table 5. Viscosity and $\mathrm{pH}$ value of duodenal and ileal digesta of White Pekin ducks (Anas platyrinchos domesticus) fed on wheatbased diets†

(Mean values)

\begin{tabular}{|c|c|c|c|c|c|c|c|c|c|c|}
\hline \multirow{2}{*}{$\begin{array}{l}\text { Wheat type... } \\
\text { Xylanase }(\mathrm{g} / \mathrm{kg}) \ldots \neq\end{array}$} & \multicolumn{3}{|c|}{ Low-viscosity } & \multicolumn{3}{|c|}{ High-viscosity } & \multirow[b]{2}{*}{ SD } & \multicolumn{3}{|c|}{$\begin{array}{c}\text { Statistical significance } \\
\text { of effect }\end{array}$} \\
\hline & $0 \cdot 0$ & 1.5 & $3 \cdot 0$ & 0.0 & $1 \cdot 5$ & $3 \cdot 0$ & & W & $X$ & $W \times X$ \\
\hline$n \S$ & 8 & 8 & 8 & 8 & 8 & 8 & - & & & \\
\hline Duodenal digesta viscosity (mPa.s)\|ף & $4 \cdot 16$ & 4.01 & $3 \cdot 86$ & $6 \cdot 03$ & 3.64 & 3.55 & 0.488 & ** & 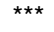 & 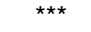 \\
\hline |leal digesta viscosity (mPa.s)\|ף & $4 \cdot 76$ & 4.48 & 4.51 & $6 \cdot 94$ & $4 \cdot 16$ & $4 \cdot 29$ & 0.685 & ** & 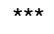 & 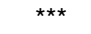 \\
\hline Duodenal digesta $\mathrm{pH}$ & $5 \cdot 39$ & $5 \cdot 48$ & $5 \cdot 41$ & $5 \cdot 36$ & $5 \cdot 45$ & $5 \cdot 39$ & 0.519 & NS & NS & NS \\
\hline lleal digesta $\mathrm{pH} \| \dagger \dagger$ & $6 \cdot 46$ & 6.45 & $6 \cdot 26$ & $5 \cdot 31$ & $6 \cdot 40$ & $6 \cdot 35$ & 0.466 & $\star \star$ & $* *$ & $* \star *$ \\
\hline
\end{tabular}

W, wheat type; $X$, xylanase $(0.0,1.5$ or $3.0 \mathrm{~g} / \mathrm{kg}$ diet $)$.

** $P<0.01,{ }^{* \star *} P<0.001$.

†For details of diets and procedures, see Tables 1 and 2 and pp. 88-89.

$\ddagger$ Xylanase preparation was derived from Trichoderma longibrachiatum and determined to contain $2590 \mathrm{units} / \mathrm{g}(1 \mathrm{unit}=1 \mu \mathrm{mol}$ reducing sugar released/min per g enzyme preparation at $40^{\circ} \mathrm{C}, \mathrm{pH} 4.8$ ).

$\S$ Number of samples for each dietary treatment (each sample pooled from six ducks within a pen).

\| Linear response to enzyme supplementation for high-viscosity wheat at $P<0.001$.

9 Quadratic response to enzyme supplementation for high-viscosity wheat at $P<0.01$.

†† Quadratic response to enzyme supplementation for high-viscosity wheat at $P<0.001$. 
Table 6. Ileal digestibilities (\%) of nutrients and energy of White Pekin ducks (Anas platyrinchos domesticus) fed on wheat-based diets† (Mean values)

\begin{tabular}{|c|c|c|c|c|c|c|c|c|c|c|}
\hline \multirow{2}{*}{$\begin{array}{l}\text { Wheat type... } \\
\text { Xylanase }(\mathrm{g} / \mathrm{kg}) \ldots \ddagger\end{array}$} & \multicolumn{3}{|c|}{ Low-viscosity } & \multicolumn{3}{|c|}{ High-viscosity } & \multirow[b]{2}{*}{ SD } & \multicolumn{3}{|c|}{$\begin{array}{c}\text { Statistical significance of } \\
\text { effect }\end{array}$} \\
\hline & 0.0 & 1.5 & $3 \cdot 0$ & 0.0 & 1.5 & $3 \cdot 0$ & & W & $X$ & $W \times X$ \\
\hline$n \S$ & 8 & 8 & 8 & 8 & 8 & 8 & - & & & \\
\hline DM\| & $77 \cdot 77$ & $81 \cdot 17$ & 81.95 & 74.64 & 78.92 & $79 \cdot 20$ & $1 \cdot 228$ & $\star * \star *$ & 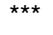 & NS \\
\hline 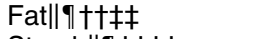 & $74 \cdot 27$ & $77 \cdot 67$ & $78 \cdot 45$ & $71 \cdot 14$ & $75 \cdot 42$ & $75 \cdot 70$ & $1 \cdot 228$ & $\star \star \star \star ~$ & $* \star *$ & NS \\
\hline 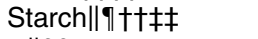 & 91.40 & 95.92 & $97 \cdot 08$ & $85 \cdot 77$ & 93.67 & 94.33 & 1.595 & $\star * \star$ & $* * *$ & $\star *$ \\
\hline 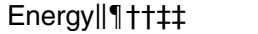 & $75 \cdot 64$ & $79 \cdot 29$ & 79.83 & $72 \cdot 27$ & $77 \cdot 04$ & $76 \cdot 70$ & 1.751 & $* \star \star$ & $* \star *$ & NS \\
\hline
\end{tabular}

W, wheat type; $X$, xylanase $(0.0,1.5$ or $3.0 \mathrm{~g} / \mathrm{kg}$ diet $)$.

${ }^{\star *} P<0.01,{ }^{\star \star \star} \quad P<0.001$

†For details of diets and procedures, see Tables 1 and 2 and pp. 88-89.

$\ddagger$ Xylanase preparation was derived from Trichoderma longibrachiatum and determined to contain $2590 \mathrm{units} / \mathrm{g}(1 \mathrm{unit}=1 \mu \mathrm{mol} \mathrm{reducing}$ sugar released/min per $\mathrm{g}$ enzyme preparation at $40^{\circ} \mathrm{C}, \mathrm{pH} 4.8$ )

$\S$ Number of samples for each dietary treatment (each sample pooled from six ducks within a pen).

\| Quadratic response to enzyme supplementation for high-viscosity wheat at $P<0.001$

१ Linear response to enzyme supplementation for low-viscosity wheat at $P<0.001$.

t† Linear response to enzyme supplementation for high-viscosity wheat at $P<0.001$.

$\ddagger \ddagger$ Quadratic response to enzyme supplementation for low-viscosity wheat at $P<0.05$.

$\S \S$ Linear response to enzyme supplementation for low-viscosity wheat at $P<0.05$.

increased the viscosities of the duodenal and ileal digesta by 45 and $56 \%$ respectively. This was accompanied by significant reductions in the ileal digestibilities of fat, starch, $\mathrm{N}$ and energy. Furthermore, the TMEn of high-viscosity wheat was significantly lower than that of low-viscosity wheat. Another objective of the present study was to investigate whether the addition of xylanase would ameliorate these effects through a reduction in viscosity of the digesta. When compared with the control group, ducks offered the diets containing high-viscosity wheat that was supplemented with xylanase at $3.0 \mathrm{~g} / \mathrm{kg}$ had 13 and $12 \%$ improvements in weight gain and gain:feed ratio respectively. Moreover, the effect of enzyme addition was more pronounced for ducks fed high-viscosity wheat, and suggested a significant interaction of wheat type $x$ xylanase. In general, the greatest digestibilities of nutrients and energy were found for ducks fed low-viscosity wheat with enzyme addition at $3.0 \mathrm{~g} / \mathrm{kg}$ diet and least for those fed high-viscosity wheat without enzyme supplementation.

Ducks fed high-viscosity wheat had greater duodenal and ileal viscosity values than those fed low-viscosity wheat, an observation that is in agreement with the studies on chickens by Choct \& Annison (1992). Due to a lack of the appropriate endogenous enzymes, water-soluble pentosans in wheat are assumed to be essentially indigestible in the upper intestinal tract of poultry and are included as part of the crude fibre fraction. These water-soluble pentosans have a remarkable capacity to attract and hold water and could directly interact with water molecules to form a large network or mesh-like structure, thereby increasing the viscosity of digesta (Bedford \& Classen, 1992). By applying an exponential equation, Dusel et al. (1998) found an excellent correlation between concentrations of water-soluble pentosans and extract viscosity. The reduction in growth performance of ducks that received the high-viscosity wheat-based diet in the present study was at least partly due to digesta viscosity. The viscous properties have adverse effects on the diffusion and convective transport of pancreatic enzymes, substrates and the endproducts of the digestion process (Isaksson et al. 1982). There is evidence that gut exposure to water-soluble pentosans can increase the thickness of mucus layer and amplify the resistance for nutrient transport through the unstirred water layer. In addition, these pentosans can promote the proliferation rate of enterocytes and change the normal morphology of villi and microvilli in chickens (Johnson \& Gee, 1986). Caution must be exercised in extrapolating the cited observation to ducks due to the fact that water intake is higher than in chickens. The water: food intake ratios are 4.2:1.0 and 2.3:1.0 for ducks and chickens respectively (Scott \& Dean, 1991). Greater water intake would result in greater digesta water content, and this could result in reduced digesta viscosity. Therefore, the negative impact of high-viscosity feed ingredients on growth performance may not be as severe in ducks as in chickens.

Anti-nutritional effects of water-soluble pentosans are known to reduce the nutritional value of wheat, triticale and rye; improvement of nutritional value through enzyme supplementation of diets that are based on these grains when fed to poultry is well documented (Annison, 1992; Bedford \& Classen, 1992). Addition of exogenous xylanase has been shown to hydrolyse the high molecular mass sub-fraction of arabinoxylan and decrease the formation of viscous solution in the digestive tracts of broiler chickens (Bedford \& Classen, 1992). The study of Steenfeldt et al. (1998) showed that xylanase has more specific activity towards cleaving bonds in the xylan backbone, especially the endosperm cell walls in wheat. As a result of the hydrolysis of polysaccharides by enzyme, the remaining polysaccharides are stripped of their capacity to produce highly viscous intestinal digesta. In the present study, we observed that supplementation of diets with xylanase reduced the viscosity of duodenal and ileal digesta in ducks fed high-viscosity wheat; this is consistent with earlier studies for broiler chickens fed wheatbased (Annison, 1992) or rye-based (Bedford \& Classen, 1992) diets. 
Ducks offered the high-viscosity wheat-based diet with added xylanase had improved weight gain and gain:feed ratios in the grower phase, but not in the starter phase. Earlier studies with broiler chickens reported similar findings (Dusel et al. 1998). Moreover, the study of Veldman \& Vahl (1994) demonstrated that there is an age effect on viscosity in chickens, which implies that xylanase supplementation would be most effective when intestinal digesta viscosity is highest (the grower phase), which coincides with higher dietary wheat levels. Enzyme supplementation not only significantly improved nutrient utilisation, but also reduced the overall variability in nutrient digestibility and led to a more consistent and uniform performance of ducks in the present study. The addition of exogenous enzyme to chicken diets was reported to increase feed passage rate and reduce digestive tract size and pancreas (Pettersson \& Aman, 1989). The latter effect was presumably the result of an adaptation to increased nutrient digestibility. The study of Brenes et al. (1993) showed that enzyme addition to wheat- or barleybased diets increased the feed consumption of broiler chickens. However, in the present study, the feed intake of ducks was not affected by the addition of enzyme to diets during the 6-week period.

Studies, mainly in broiler chickens, that have investigated mechanisms by which exogenous enzymes enhance nutrient digestion and utilisation in wheat and other ingredients suggest that growth performance response to enzyme supplementation is not always associated with digesta viscosity (Annison et al. 1995; Hew et al. 1998); thus, characteristics other than viscosity were also responsible for the observed improvements. The slower rate of feed passage and presence of significant amounts of undigested materials likely encourages proliferation of microflora in the small intestine. By fermenting and utilising carbohydrate and protein, the microflora compete with the host for nutrients and this may contribute, at least in part, to the adverse effect of wheat pentosans (Choct et al. 1996). More recent work, in which germ-free and conventional birds were fed highly viscous diets, established that the negative effects of viscosity were virtually absent in germ-free birds (Langout et al. 2000; JB Schutte and DJ Langhout, unpublished results). The study of Bedford \& Apajalahti (2001) demonstrated that in birds fed a reasonable quality wheat-based diet, the addition of a xylanase-based enzyme resulted in a $60 \%$ reduction in microbial numbers. The significantly higher ileal $\mathrm{pH}$ values in the present study may be a consequence of decreasing microbial colonisation, thereby reducing volatile fatty acids in the ileum of ducks that received xylanase-supplemented diets. Indeed, Langhout et al. (2000) showed in broiler chickens that the addition of viscosityproducing citrus pectin was associated with an increase in both microbial counts and lactic acid concentration, as well as a decrease in $\mathrm{pH}$ of ileal digesta.

Intestinal digestion and absorption of lipids depends on adequate secretion of bile salts, which are essential for emulsification of fats and activation of lipase (Dänickle et al. 2000). Studies by Jaroni et al. (1999) showed that NSP could increase the average retention time of chyme in the gastrointestinal tract and could provide relatively more substrate for utilisation by microbes. An increased bacterial activity could increase the deconjugation of bile acids, resulting in an impairment of entero-hepatic recirculation bile acids. As a result, poor digestion of fat may occur due to the reduced concentration of bile salts in the digesta. With xylanase supplementation of diets, microbial deconjugation of bile salts is presumably restricted: this may account for the improvement of ileal digestibility of fat seen in the present study. We are at a loss to explain the observed tendency of a reduction in apparent $\mathrm{N}$ retention when xylanase was added to the low-viscosity wheat; however, two ducks in each of the treatments with added xylanase at 1.5 or $3.0 \mathrm{~g} / \mathrm{kg}$ had considerably high excreta $\mathrm{N}$ output and thus low $(<30 \%) \mathrm{N}$ digestibility.

Wheat starch generally comprises slowly digested starch and resistant starch. Enzyme supplementation of diets could disrupt endosperm cell-wall integrity and break down the viscous NSP, allowing amylase access to starch and thus improving the digestibility of starch. In experiments with a xylanase-supplemented barley-based diet in broiler chickens, Ankrah et al. (1999) reported a considerable reduction in ileal digesta viscosity and an improvement in starch digestibility. With a wheat-based diet, reduction in viscosity and an increase in starch digestibility were moderate (Marron et al. 2001). The ileal digestibility of the starch in a wheat-based diet was improved from 88 to $96 \%$ in broiler chickens by enzyme supplementation (Annison 1992); this is in agreement with the increase from 85 to $94 \%$ for ducks in the present study. The study of Dusel et al. (1998) demonstrated that xylanase supplementation tended to improve the $\mathrm{N}$-corrected metabolisable energy. There are significant linear correlations between metabolisable energy values and both the coefficients of starch digestibility and the contents of digestible starch in vivo for broiler chickens (Wiseman et al. 2000). Therefore, the improvement in TME in the present study was probably due to increases in fat and starch digestibilities.

In summary, the present results indicate that the reduction in growth performance of ducks fed high-viscosity wheat is related to an increase in viscosity of duodenal and ileal digesta and a subsequent decrease in utilisation of nutrients. As such, viscosity may be a credible quality response criterion for estimation of the nutritive value of wheat for ducks. Further, supplementation of the high-viscosity wheat-based diet with xylanase mitigated the growth performance reduction with accompanying decreases in duodenal and ileal digesta viscosities and a subsequent increase in nutrient utilisation. We believe this to be the first confirmation of exogenous dietary xylanase amelioration of viscosity-induced anti-nutritional effects in wheat-based diets for ducks.

\section{References}

Adeola O, Ragland D \& King D (1997) Feeding and excreta collection techniques in metabolizable energy assays for ducks. Poult Sci 76, 728-732.

Ankrah NO, Campbell GL, Tyler RT, Rossnagel BG \& Sokhansanj SRT (1999) Hydrothermal and $\beta$-glucanase effects 
on the nutritional and physical properties of starch in normal and waxy hull-less barley. Anim Feed Sci Technol 81, 205-219.

Annison G (1992) Commercial enzyme supplementation of wheat based diets raises ileal glucanase activities and improves apparent metabolizable energy, starch and pentosan digestibilities in broiler chickens. Anim Feed Sci Technol 38, 105-121.

Annison G, Chot M \& Hughes RJ (1995) Enzymes and the nutritive value of lupins. In Proceedings of Australian Poultry Science Symposium, pp. 126-130. Sydney: Sydney University.

Association of Official Analytical Chemists (1995) Official Methods of Analysis, 16th ed. Arlington, VA: AOAC.

Bedford MR \& Apajalahti J (2001) Microbial interactions in the response to exogenous enzyme utilisation. In Enzymes in Farm Animal Nutrition, pp. 299-314 [MR Bedford and GG Patridge, editors]. Wallingford, Oxon.: CABI Publishing.

Bedford MR \& Classen HL (1992) Reduction of intestinal viscosity through manipulation of dietary rye and pentosanase concentration is affected through changes in carbohydrate composition of the intestinal aqueous phase and results in improved growth rate and feed conversion efficiency of broiler chicks. $J$ Nutr 122, 560-569.

Brenes A, Smith M, Guenter W \& Marquardt RR (1993) Effect of enzyme supplementation on the performance and digestive tract size of broiler chickens fed wheat- and barley-based diets. Poult Sci 72, 1731-1739.

Carre B, Idi A, Maisonnier S, Melcion J-P, Oury F-X, Gomez J \& Pluchard P (2002) Relationships between digestibility of food components and characteristics of wheats (Triticum aestivum) introduced as the only cereal source in broiler diet. Br Poult Sci 43, 404-415.

Choct M \& Annison G (1992) Anti-nutritive activity of the wheat pentosans in broiler chicken: role of viscosity and gut microflora. Br Poult Sci 33, 821-834.

Choct M, Hughes RJ, Wang J, Bedford MR, Morgan AJ \& Annison G (1996) Increased small intestinal fermentation is partly responsible for the anti-nutritive activity of non-starch polysaccharides in chickens. Br Poult Sci 37, 609-621.

Czarnocki J, Sibbald IR \& Evans EV (1961) The determination of chromic oxide in samples of feed and excreta by acid digestion and spectrophotometry. Can J Anim Sci 41, 167-179.

Dänickle S, Simon O \& Jeroch H (2000) Estimation of endogenous $\mathrm{N}$-losses in broilers by a ${ }^{15} \mathrm{~N}$ isotope dilution technique: effect of dietary fat type and xylanase addition. Arch Anim Nutr 53, 75-97.

Dusel G, Kluge H \& Jeroch H (1998) Xylanase supplementation of wheat-based rations for broilers: influence of wheat characteristics. Appl Poult Sci Res 7, 119-131.

Fincher GB \& Stone BA (1986) Cell walls and their components in cereal grain technology. In Advances in Cereal Science and Technology, vol. 8, pp. 207-295 [Y Pomeranz, editor]. St Paul, MN: AACC.

Friesen OD, Guenter W, Marquardt RR \& Rotter BA (1992) The effect of enzymes on the apparent metabolizable energy and nutrient digestibilities of wheat, barley, and rye for the young broiler chicks. Poult Sci 71, 1710-1721.
Hew LI, Ravindran V, Mollah Y \& Bryden WL (1998) Influence of exogenous xylanase supplementation on apparent metabolisable energy and amino acid digestibility in wheat for broiler chickens. Anim Feed Sci Technol 75, 83-92.

Isaksson G, Lundquist I \& Ihse I (1982) Effect of dietary fiber on pancreatic enzyme activity in vitro: the importance of viscosity, $\mathrm{pH}$, ionic strength, absorption and time of incubation. Gastroenterology 82, 918-924.

Jaroni D, Scheideler SE, Beck MM \& Wyatt C (1999) The effect of dietary wheat middlings and enzyme supplementation II. Apparent nutrient digestibility, digestive tract, gut viscosity, and gut morphology in two strains of leghorn hens. Poult Sci 78, 1664-1674.

Johnson IT \& Gee JM (1986) Gastrointestinal adaptation in response to soluble non-available polysaccharides in the rat. Br J Nutr 55, 497-505.

King D, Fan MZ, Ejeta G, Asem EK \& Adeola O (2000) The effects of tannins on nutrient utilisation in the White Pekin duck. Br Poult Sci 41, 630-639.

Langhout DJ, Schutte JB, de Jong J, Sloetjes H, Verstegen MWA \& Tamminga S (2000) Effect of viscosity on digestion of nutrients in conventional and germ-fee chicks. Br J Nutr 83, 533-540.

McNab JM \& Blair JC (1988) Modified assay for true and apparent metabolizable energy based on the tube feeding. $\mathrm{Br}$ Poult Sci 26, 697-707.

Marron L, Bedford MR \& McCracken KJ (2001) The effects of adding xylanase, vitamin $\mathrm{C}$ and copper sulphate to wheat-based diets on broiler performance. Br Poult Sci 42, 493-500.

Pettersson D \& Aman P (1989) Enzyme supplementation of a poultry diet containing rye and wheat. Br J Nutr 62, 139-149.

Scott ML \& Dean WF (1991) Nutrition and Management of Ducks. Ithaca, NY: M L Scott of Ithaca.

Scott TA, Silversides FG, Classen HL, Swift ML \& Bedford MR (1998) Effect of cultivar and environment on the feeding value of Western Canadian wheat and barley samples with and without enzyme supplementation. Can J Anim Sci 78, 649-656.

Sibbald IR (1976) A bioassay for true metabolizable energy in feedstuffs. Poult Sci 55, 303-308.

Sibbald IR (1979) A bioassay for available amino acids and true metabolizable energy in feedingstuffs. Poult Sci 58, 668-673.

Steenfeldt S, Mũllertz A \& Jensen JF (1998) Enzyme supplementation of wheat-based diets for broilers. I. Effect on growth performance and intestinal viscosity. Anim Feed Sci Technol 75, 27-43.

Veldman A \& Vahl HA (1994) Xylanase in broiler diets with differences in characteristics and content of wheat. $\mathrm{Br}$ Poult Sci 35, 537-550.

Wiseman J, Nicol NT \& Norton G (2000) Relationship between apparent metabolisable energy (AME) values and in vivo / vitro starch digestibility of wheat for broilers. Worlds Poult Sci J 56, 305-318. 